\title{
COVID-19 Patient Mortality with Convalescent Plasma Therapy: Meta-Analysis
}

\author{
Fathiyyatu Assa'diy Firda'), Bhisma Murti'1), Cri Sajjana \\ Prajna Wekadigunawan'2)
}

\author{
1)Masters Program in Public Health, Universitas Sebelas Maret \\ 2)Universitas Esa Unggul, Jakarta, Indonesia
}

\section{ABSTRACT}

Background: The use of convalescent plasma was recommended as empiric treatment during the Ebolavirus outbreak in 2014, and a protocol for the treatment of Middle East Respiratory Syndrome coronavirus (MERS) with convalescent plasma was created in 2015. These findings raise the hypothesis that the use of convalescent plasma transfusion may be beneficial in SARS-infected patients. -CoV-2. The aim of this study was to estimate the mortality risk of COVID-19 patients with convalescent plasma therapy.

Subjects and method: A systematic review and meta-analysis was carried out by collecting articles from the Google Scholar, PubMed, and Science Direct databases. The articles were screened using the PICO model, including: (1) Population= confirmed COVID-19 patients, (2) Intervention= convalescent plasma therapy, (3) Comparison= standard of care, and (4) Outcome= mortality. The keywords used were "Convalescent plasma therapy" OR "Convalescent plasma transfusion" AND "Mortality" OR "death" AND "COVID-19" OR "Coronavirus disease 2019" OR "SARS-Cov-2'. Inclusion criteria were full text, randomized control trials, published from 2020 to 2021, and reported risk ratios. Articles were collected using PRISMA diagrams and quantitative syntheses were assessed using Review Manager (RevMan 5.3).

Results: The meta-analysis was conducted using 9 randomized controlled trial articles involving 4,540 confirmed COVID-19 patients from India, Bahrain, Chile, Netherlands, United States, China, Argentina, New York, and Brazil. This study showed that convalescent plasma therapy reduced mortality in confirmed COVID-19 patients, and was statistically significant $(\mathrm{RR}=0.77 ; 95 \% \mathrm{CI}=$ 0.64 to $0.93 ; \mathrm{p}=0.008$ ). The heterogeneity of the study data showed $\mathrm{I}^{2}=3 \%$, we found significant inter-study heterogeneity and estimates were made using the fixed effect model.

Conclusion: Convalescent plasma therapy reduces mortality in confirmed COVID-19 patients, and is statistically significant.

Keywords: COVID-19, convalescent plasma therapy, mortality

\section{Correspondence:}

Fathiyyatu Assa'diy Firda. Masters Program in Public Health, Universitas Sebelas Maret. Jl. Ir. Sutami 36A, Surakarta 57126, Central Java. Email: fathiyyatu.firda98@gmail.com. Mobile: 089516880479.

Cite this as:

Firda FA, Murti B, Wekadigunawan CSP (2021). COVID-19 Patient Mortality with Convalescent Plasma Therapy: Meta-Analysis. J Epidemiol and Public Health. 06(02): 281-291. https://doi.org/10.26911/jepublichealth.2021.06.03.02.

Journal of Epidemiology and Public Health is licensed under a Creative Commons Attribution-NonCommercial-ShareAlike 4.o International License.

\section{BACKGROUND}

Infection with Severe acute respiratory syndrome coronavirus 2 (SARS-CoV-2), a new single-stranded RNA (ribonucleic acid) virus variant belonging to the coronavirus family, has received global attention, and the World Health Organization (WHO) declared the disease corona virus disease 2019 (COVID-19) as a Public Health Emergency of International Concern on 30 January 
2020, and a pandemic on 11 March 2020. Between 31 December 2019 and 29 July 2020, more than 16 million cases of COVID19 were reported worldwide, accounting for more than 660,000 death. Most COVID-19 patients have mild disease and recover without any treatment. However, older individuals with comorbidities such as diabetes mellitus, hypertension, and respiratory or cardiovascular disease have a greater risk of complications and death (Choi, 2020).

Several treatments have been shown to be effective for COVID-19. Administration of convalescent plasma, which is widely used in viral infections that induce neutralizing antibodies. It is used during outbreaks of severe acute respiratory illness caused by other coronaviruses, SARS-CoV-1 and MERS-CoV, with varying results and when given early, it reduces the length of hospital stay. The use of convalescent plasma has an acceptable safety profile and its administration is a viable approach to adopt during a pandemic. In COVID-19, it may reduce the viral load, improve clinical status, and decrease mortality. On March 24, 2020, the Food and Drug Administration of the United States (FDA) launched an expanded Access Program to collect convalescent plasma donated by individuals who have recovered from COVID-19, and on August 23, 2020 approved emergency use. A study conducted on 20,000 patients confirmed the safety of convalescent plasma. Whereas in a study of 30,000 patients, the same group of investigators showed a reduction in mortality when convalescent plasma was administered early in the course of COVID-19. Convalescent plasma is currently being evaluated in 126 clinical trials (M. Salazar et al., 2021).

Meta-analysis is an epidemiological design that aims to systematically examine and combine quantitative estimation results from a number of previous studies that answer the same research problem and can be combined (Mikolajewicz \& Komarova, 2019). Many primary studies have investigated the effect of convalescent plasma therapy on reducing mortality in COVID-19 patients. Further analysis is needed to arrive at a convincing conclusion.

The aim of this study was to estimate the risk of death of COVID-19 patients with convalescent plasma therapy.

\section{SUBJECTS AND METHOD}

\section{Study Design}

The design of this study is a systematic review and meta-analysis that uses secondary data from previous research results from the Google Scholar, PubMed, and Science Direct databases with the range of 20202021. The search keywords for the article were as follows: "Convalescent plasma therapy" OR "Convalescent plasma transfusion" AND "Mortality" OR "death" AND "COVID-19" OR "Coronavirus disease 2019" OR "SARS-Cov-2".

\section{Inclusion Criteria}

The inclusion criteria in this study were full paper articles using an RCT (Randomized Control Trial) study design, the relationship measure used was the Risk Ratio, the study subjects were patients with confirmed COVID-19, the intervention provided was convalescent plasma therapy, and the outcome of the study was mortality (death).

\section{Exclusion Criteria}

Articles published in languages other than English, duplicated articles, Observational studies, articles before 2020

\section{Operational Definition of Variable}

Convalescent plasma therapy is the administration of blood plasma from patients who have recovered from COVID-19 with certain criteria given as passive immunity in patients with COVID-19. 


\section{Data Analysis}

Data processing in this study was carried out by identifying articles obtained from several databases, followed by screening to obtain articles that met the requirements. Then the quality of the study was assessed using the Critical Appraisal of a Randomized Control Study from the Center for Evidence Based Management (CEBM). The articles that passed this stage were analyzed using RevMan 5.3 Software.

\section{RESULTS}

The initial search process in the database yielded 1472 articles and there were additional 38 articles identified from other searches, then through the process of deleting duplicate articles as many as 458 articles with 1052 articles filtered of which qualified for further full text review. The results of the articles that met the qualitative requirements were reviewed again and there were 9 articles that met the quantitative requirements (Figure 1).

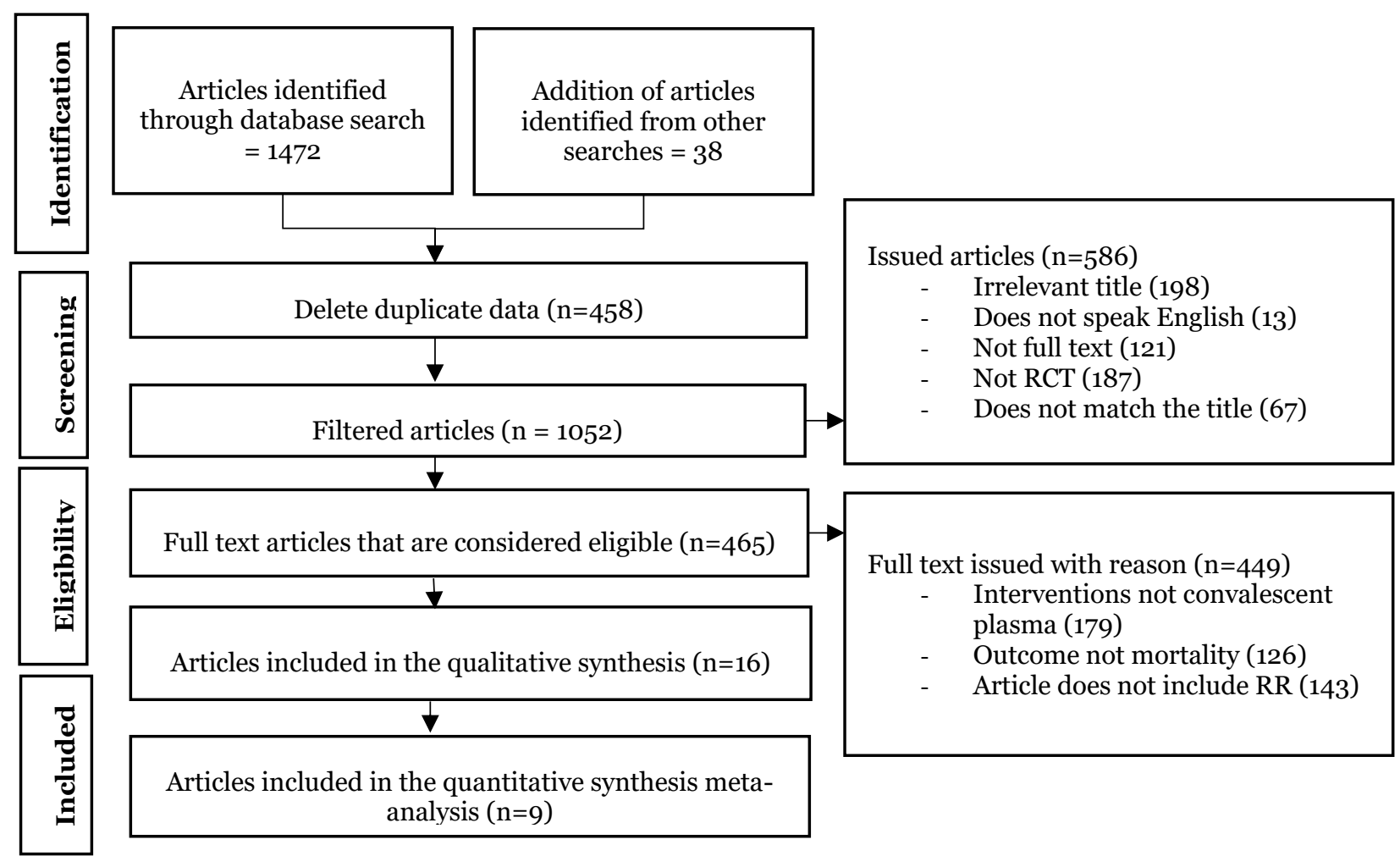

Figure 1. PRISMA flow diagram

The forest plot can be seen in Figure 2, the results of the meta-analysis in the study of convalescent plasma therapy reduced the risk of death in COVID-19 patients and were statistically significant $(\mathrm{RR}=0.77 ; 95 \% \mathrm{CI}=$ 0.64 to $0.93 ; \mathrm{p}=0.008)$. The heterogeneity of the research data shows $I^{2}=3 \%$. The heterogeneity $\left(\mathrm{I}^{2}\right)$ of this meta-analysis was less than $50 \%$ so we calculated the relative risk (RR) using the fixed effect model (Akobeng, 2005 in Murti, 2018). 
Table 1. Description of the primary studies in the meta-analysis

\begin{tabular}{|c|c|c|c|c|c|c|c|c|}
\hline $\begin{array}{l}\text { Author } \\
\text { (year) }\end{array}$ & Title & Country & $\begin{array}{l}\text { Study } \\
\text { Design }\end{array}$ & Sample & $\begin{array}{c}\mathbf{P} \\
\text { Population } \\
\end{array}$ & $\begin{array}{c}\text { I } \\
\text { Intervention } \\
\end{array}$ & $\begin{array}{c}\mathbf{C} \\
\text { Comparison } \\
\end{array}$ & $\begin{array}{c}\text { O } \\
\text { Outcome } \\
\end{array}$ \\
\hline $\begin{array}{l}\text { Agarwal et } \\
\text { al. (2020) }\end{array}$ & $\begin{array}{l}\text { Convalescent plasma in the } \\
\text { management of moderate } \\
\text { covid-19 in adults in India: } \\
\text { open label phase II } \\
\text { multicentre randomised } \\
\text { controlled trial }\end{array}$ & India & RCT & 464 & $\begin{array}{l}\text { Moderate COVID-19 } \\
\text { patients in } 39 \text { public and } \\
\text { private hospitals in India }\end{array}$ & $\begin{array}{l}\text { Convalescent } \\
\text { Plasma 2x200 ml }\end{array}$ & $\begin{array}{l}\text { Standard of } \\
\text { care }\end{array}$ & $\begin{array}{l}\text { Severe disease } \\
\text { progression }(\mathrm{PaO} 2 / \mathrm{FiO} 2 \\
<100 \mathrm{~mm} \mathrm{Hg}) \text { and all- } \\
\text { cause mortality at } 28 \\
\text { days }\end{array}$ \\
\hline $\begin{array}{l}\text { Al-Qahtani } \\
\text { et al. (2021) }\end{array}$ & $\begin{array}{l}\text { Randomized controlled trial of } \\
\text { convalescent plasma therapy } \\
\text { against standard therapy in } \\
\text { patients with severe COVID-19 } \\
\text { disease }\end{array}$ & Bahrain & RCT & 40 & $\begin{array}{l}\text { COVID-19 patients } \\
\text { requiring oxygen therapy } \\
\text { and radiological evidence } \\
\text { of pneumonia }\end{array}$ & $\begin{array}{l}\text { Convalescent } \\
\text { Plasma } 200 \mathrm{ml}\end{array}$ & $\begin{array}{l}\text { Standard of } \\
\text { care }\end{array}$ & $\begin{array}{l}\text { Need for ventilator, } \\
\text { leukocyte count, actate } \\
\text { dehydrogenase (LDH), C- } \\
\text { reactive protein (CRP), } \\
\text { Troponin, Ferritin, D- } \\
\text { Dimer, procalcitonin, } \\
\text { mortality at } 28 \text { days }\end{array}$ \\
\hline $\begin{array}{l}\text { Balcells et al. } \\
\text { (2021) }\end{array}$ & $\begin{array}{l}\text { Early versus deferred anti- } \\
\text { SARS-CoV-2 convalescent } \\
\text { plasma in patients admitted } \\
\text { for COVID-19: A randomized } \\
\text { phase II clinical trial }\end{array}$ & $\begin{array}{l}\text { Santiago, } \\
\text { Chili }\end{array}$ & RCT & 57 & $\begin{array}{l}\text { Patients hospitalized } \\
\text { within the first } 7 \text { days of } \\
\text { COVID-19 symptoms, } \\
\text { exhibiting risk factors for } \\
\text { disease progression, } \\
\text { without mechanical } \\
\text { ventilation }\end{array}$ & $\begin{array}{l}\text { Convalescent } \\
\text { plasma } 400 \mathrm{ml}\end{array}$ & $\begin{array}{l}\text { Standard of } \\
\text { care }\end{array}$ & $\begin{array}{l}\text { Need for mechanical } \\
\text { ventilation, } \\
\text { hospitalization }>14 \text { days, } \\
\text { or hospital death }\end{array}$ \\
\hline $\begin{array}{l}\text { Gharbharan } \\
\text { et al. (2020) }\end{array}$ & $\begin{array}{l}\text { Convalescent Plasma for } \\
\text { COVID-19. A randomized } \\
\text { clinical trial }\end{array}$ & $\begin{array}{l}\text { Netherla } \\
\text { nd }\end{array}$ & RCT & 86 & $\begin{array}{l}\text { Hospitalized COVID-19 } \\
\text { patients in the } \\
\text { Netherlands }\end{array}$ & $\begin{array}{l}\text { Convalescent } \\
\text { plasma minimum } \\
\text { 1x300 ml with } \\
\text { neutralizing } \\
\text { antibody titer } \\
\text { PRNT50 > 1:80 }\end{array}$ & $\begin{array}{l}\text { Standard of } \\
\text { care }\end{array}$ & $\begin{array}{l}\text { Mortality on day 60, } \\
\text { length of hospitalization, } \\
\text { and increase in WHO 8- } \\
\text { point disease severity } \\
\text { scale on day } 15\end{array}$ \\
\hline $\begin{array}{l}\text { Joyner et al. } \\
\text { (2021) }\end{array}$ & $\begin{array}{l}\text { Convalescent Plasma Antibody } \\
\text { Levels and the Risk of Death } \\
\text { from Covid-19 }\end{array}$ & $\begin{array}{l}\text { The } \\
\text { United } \\
\text { States }\end{array}$ & RCT & 3.082 & $\begin{array}{l}\text { Adult patient with Covid- } \\
19 \text { hospitalized }\end{array}$ & $\begin{array}{l}\text { Convalescent } \\
\text { plasma low titer, } \\
\text { medium titer, and } \\
\text { high titer }\end{array}$ & $\begin{array}{l}\text { Standard of } \\
\text { care }\end{array}$ & $\begin{array}{l}\text { death within } 30 \text { days } \\
\text { after plasma transfusion }\end{array}$ \\
\hline $\begin{array}{l}\text { Li et al. } \\
(2020)\end{array}$ & $\begin{array}{l}\text { Effect of Convalescent Plasma } \\
\text { Therapy on Time to Clinical } \\
\text { Improvement in Patients With } \\
\text { Severe and Life-threatening } \\
\text { COVID-19: A Randomized } \\
\text { Clinical Trial }\end{array}$ & China & RCT & 101 & $\begin{array}{l}\text { Severe/critical COVID-19 } \\
\text { patients in } 7 \text { hospitals in } \\
\text { India }\end{array}$ & $\begin{array}{l}\text { Convalescent } \\
\text { Plasma 1X20oml } \\
\text { with S-RBD- } \\
\text { specific Ig-G titer } \\
>1: 640\end{array}$ & $\begin{array}{l}\text { Standard of } \\
\text { care }\end{array}$ & $\begin{array}{l}\text { Clinical improvement } \\
\text { within } 28 \text { days, mortality } \\
\text { at } 28 \text { days, time to } \\
\text { hospital discharge, and } \\
\text { PCR results changing } \\
\text { from positive at baseline }\end{array}$ \\
\hline
\end{tabular}


Firda et al./ Covid-19 Patient Mortality with Convalescent Plasma Therapy

\begin{tabular}{|c|c|c|c|c|c|c|c|c|}
\hline $\begin{array}{l}\text { Libster et al. } \\
(2021)\end{array}$ & $\begin{array}{l}\text { Early High-Titer Plasma } \\
\text { Therapy to Prevent Severe } \\
\text { Covid-19 in Older Adults }\end{array}$ & $\begin{array}{l}\text { Argentin } \\
\text { a }\end{array}$ & RCT & 160 & $\begin{array}{l}\text { Mild COVID-19 patients, } \\
\text { symptom onset }<72 \\
\text { hours old age/with } \\
\text { comorbidities }\end{array}$ & $\begin{array}{l}\text { Convalescent } \\
\text { Plasma 1x250 ml, } \\
\text { Ig-G spike titer } \\
\text { requirement } \\
\text { 1:1000 }\end{array}$ & $\begin{array}{l}\text { Standard of } \\
\text { care }\end{array}$ & $\begin{array}{l}\text { Development of severe } \\
\text { respiratory disease, } \\
\text { critical systemic illness, } \\
\text { death }\end{array}$ \\
\hline $\begin{array}{l}\text { O'Donnell et } \\
\text { al. (2021) }\end{array}$ & $\begin{array}{l}\text { A randomized double-blind } \\
\text { controlled trial of convalescent } \\
\text { plasma in adults with severe } \\
\text { COVID-19 }\end{array}$ & $\begin{array}{l}\text { New } \\
\text { York \& } \\
\text { Brazil }\end{array}$ & RCT & 223 & $\begin{array}{l}\text { Hospitalized adult } \\
\text { patients with severe and } \\
\text { critical COVID-19 at } 5 \\
\text { locations in New York } \\
\text { City (USA) and Rio de } \\
\text { Janeiro (Brazil) }\end{array}$ & $\begin{array}{l}\text { Convalescent } \\
\text { Plasma 200-250 } \\
\text { ml with a total } \\
\text { anti-SARS-CoV-2 } \\
\text { IgG antibody titer } \\
\text { of at least 1:400 }\end{array}$ & $\begin{array}{l}\text { Standard of } \\
\text { care }\end{array}$ & $\begin{array}{l}\text { Clinical status at } 28 \text { days } \\
\text { after randomization and } \\
\text { death at } 28 \text { days }\end{array}$ \\
\hline $\begin{array}{l}\text { Simonovich } \\
\text { et al. (2021) }\end{array}$ & $\begin{array}{l}\text { A Randomized Trial of } \\
\text { Convalescent Plasma in Covid- } \\
19 \text { Severe Pneumonia }\end{array}$ & $\begin{array}{l}\text { Argentin } \\
\mathrm{a}\end{array}$ & RCT & 327 & $\begin{array}{l}\text { Severe COVID-19 patient } \\
\text { in Argentina }\end{array}$ & $\begin{array}{l}\text { Convalescent } \\
\text { Plasma } 1 \times 500 \mathrm{ml} \text {, } \\
\text { requirement for } \\
\text { ig-G spike titer } \\
\text { 1:400 }\end{array}$ & $\begin{array}{l}\text { Standard of } \\
\text { care }\end{array}$ & $\begin{array}{l}\text { Death, invasive } \\
\text { ventilation support, need } \\
\text { for supplemental oxygen, } \\
\text { and hospital discharge up } \\
\text { to day } 30\end{array}$ \\
\hline
\end{tabular}


Firda et al./ Covid-19 Patient Mortality with Convalescent Plasma Therapy

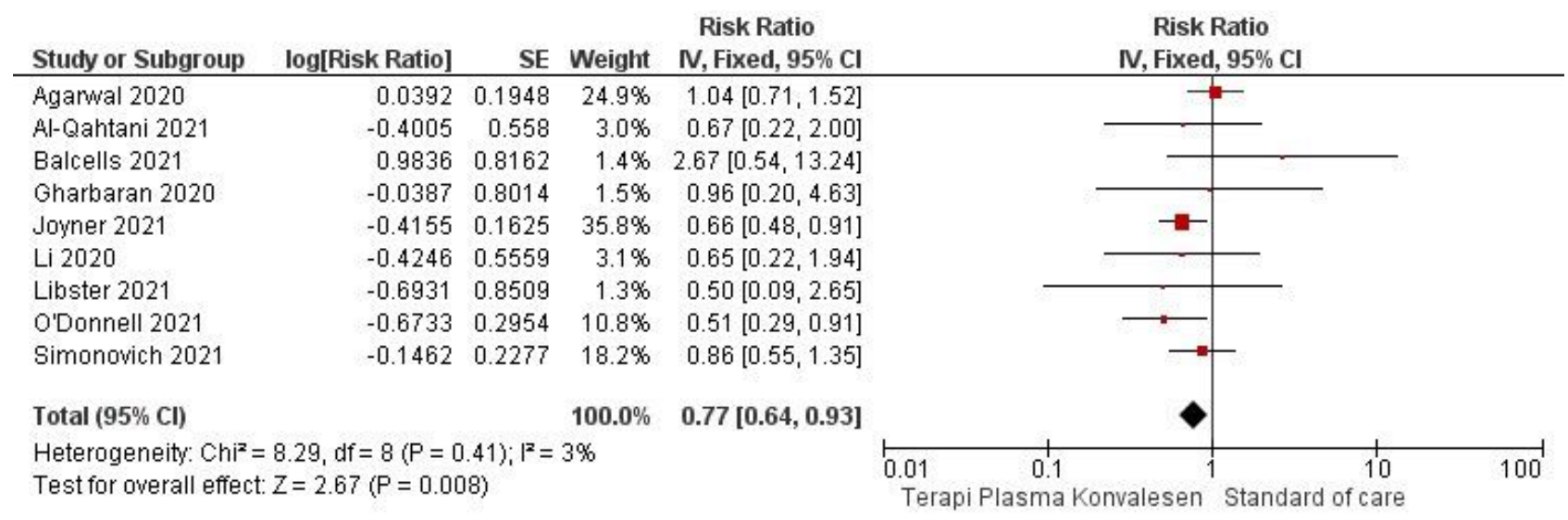

Figure 2. Forest Plot Effect of Convalescent Plasma Therapy on Mortality of COVID-19 Patients.

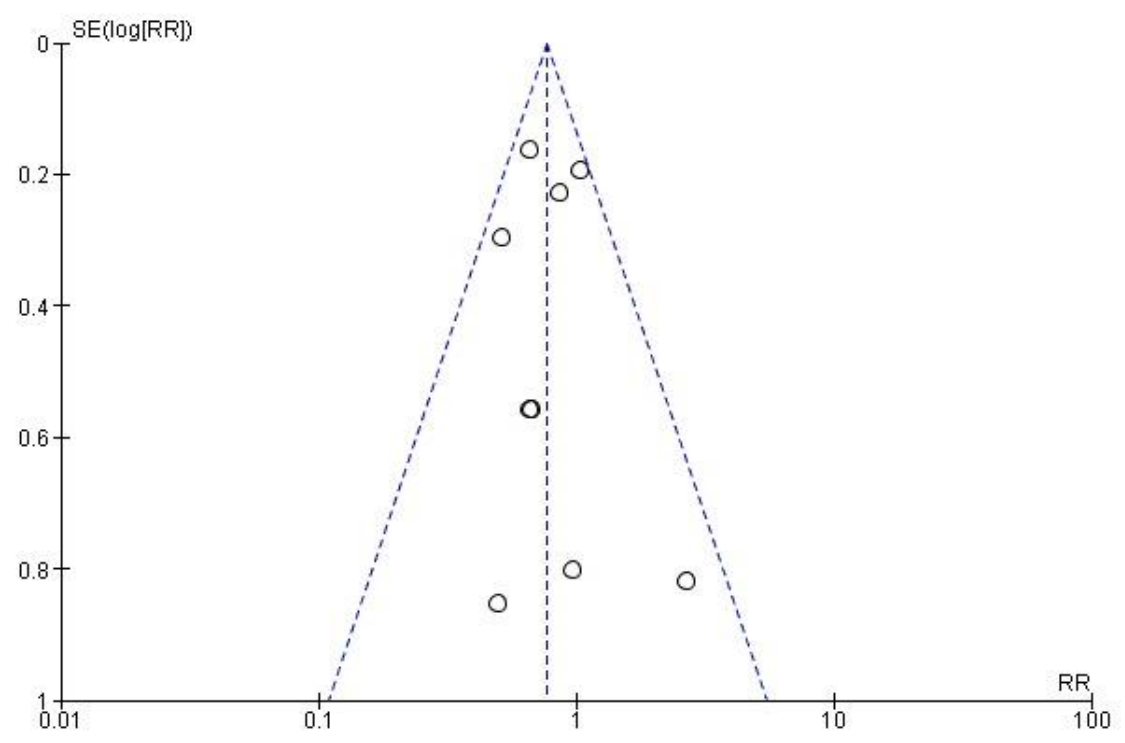

\section{Figure 3. Funnel Plot Effect of Convalescent Plasma Therapy on Mortality of COVID-19 Patients}

The funnel plot can be seen in Figure 3, it shows that there is no publication bias which is indicated by the symmetry between the right and left plots.

\section{DISCUSSION}

Since the publication of the first case series from China, several studies have reported an association between convalescent plasma and reduced mortality, hospitalization, and viral load in patients with COVID-19 (Joyner et al., 2020). A study conducted by Agarwal et al. (2020) revealed that there was no difference in 28-day mortality in moderategrade COVID-19 patients treated with convalescent plasma. This is because the recipient has a higher neutralizing antibody titer than the convalescent plasma donor antibody titer. In addition, donors who are younger and have milder symptoms than recipients may drive this difference.

In the study (AlQahtani et al., 2021), patients who received early CP (less than 3 days from admission) had higher mean 
antibody levels in transfused plasma, than those who received $\mathrm{CP}$ after 3 days, although the difference was not significant. Significant. A previous study by Joyner et al., (2020), reported that patients who received early CP and with higher antibody titers performed better clinically. CP collected from donors showed variation in mean antibody levels, some extending to very low levels. The variability of antibody levels may affect plasma effectiveness and may decrease the effect of $\mathrm{CP}$ in this trial. The FDA has recommended using CPs with high antibody titers only, to prevent transfusions of CPs with low antibody levels which could be ineffective.

In this study (Balcells et al., 2021), the Anti Nab titer test using a sample with a neutralizing activity of at least $50 \%$ at a dilution of 1:160 was considered positive and was used to perform the titration curve and calculate the neutralization titer of the $50 \%$ inhibitory dose (ID50). The clearance rates of SARS-CoV-2 PCR on nasopharyngeal swabs also did not differ between study groups, suggesting that convalescent plasma administration in this study did not confer sufficient antiviral activity in patients with COVID-19 at this stage.

In the study (Li et al., 2020), a randomized controlled trial of 103 patients with severe and life-threatening COVID-19 in China. In that trial, a subgroup of 45 patients with severe disease showed no significant difference in the secondary outcome of 28day mortality or time from randomization to discharge. Convalescent plasma treatment was associated with higher levels of negative SARS-CoV-2 virus PCR results from nasopharyngeal swabs at 24,48 , and 72 hours, suggesting that convalescent plasma treatment is associated with antiviral activity in patients with COVID-19.

In the study (Gharbharan et al., 2020), the ConCOVID trial from the Netherlands, which was terminated prematurely after 86 patients had enrolled, did not find any effect on death at 60 days, hospital stay, or disease severity at 15 days. The majority of patients in the ConCOVID study already had high viral neutralizing antibody titers on the day of study inclusion with titers comparable to 115 screen-recovered donors for convalescent plasma donation. When the study was designed, the timing of the development of neutralizing antibodies after SARS-CoV-2 infection was uncertain and the investigators considered it unlikely that most patients would have autologous neutralizing antibodies on the day of hospital admission. Almost all plasma donors had anti-SARSCoV-2 antibodies but only $41 \%$ had a high neutralizing titer of at least 1:320. The solution might be to actively recruit recovered patients who have more severe COVID-19 disease as donors, as they have been shown to have higher antibody levels (Okba et al., 2020).

In the study of Joyner et al., (2021), reported that 7-day mortality and 30-day mortality were lower in those who received recovery plasma within three days of symptom onset. In patients with COVID-19 who were not receiving mechanical ventilation, plasma transfusions with high antibody levels were associated with a lower risk of death than plasma transfusions with low antibody levels. In addition, patients who received plasma within 3 days of receiving a Covid-19 diagnosis had a lower risk of death than those who received the transfusion later in the course of the disease.

In the study of O'Donnell et al., (2021), In this randomized, blinded, controlled phase 2 trial conducted in New York City and Rio de Janeiro, treatment with convalescent plasma compared with control plasma did not result in significant clinical improvement. at 28 days, based on an ordinal scale of clinical status, among adults 
hospitalized with severe and critically ill COVID-19. However, mortality at 28 days was significantly lower among patients randomized to convalescent plasma. This effect on mortality was observed across analyzes adjusted for imbalances in baseline variables with prognostic relevance and in sensitivity analyzes performed to account for 28-day uncertain vital status in 8 patients. Although limited, available data suggest that the efficacy of treatment for convalescent plasma may depend on the duration of the disease and the severity and neutralizing titer of anti-SARS-CoV-2 antibodies in transfused plasma.

In one study (Libster et al., 2021), reported the use of convalescent plasma in older patients early in the course of Covid19. Administration of convalescent plasma with high antibody titers against SARS-CoV2 to infected patients within 72 hours of symptom onset reduced the risk of progression to severe respiratory disease by $48 \%$. Researchers aim to stop disease progression early and at a mild stage. The researcher's main end point was enrollment criteria in previous studies.

In a study (Simonovich et al., 2021), a recent clinical trial from Argentina reported that transfusion of high-titer convalescent plasma within 72 hours of symptom onset prevented progression of severe disease among elderly adults with mild COVID-19. High-titer convalescent plasma was associated with increased mortality among hospitalized patients who did not receive an invasive mechanical ventilator (IMV) at the time of transfusion. Although clinical status at 28 days did not differ significantly between the treatment groups, 28-day mortality was significantly lower among patients randomized to receive plasma recovery.

In several studies that did not find a clinical benefit of convalescent plasma therapy in these patients could be explained by several reasons. First, humoral immunity may not play a major role in the subset of patients who have initiated a highly proinflammatory response and in whom inflammation and coagulopathy may be more important than viral replication in disease progression (Polidoro et al., 2020). It is not known whether selection of plasma units with very high concentrations of NAbs or larger plasma volumes can successfully blunt this disordered inflammatory response. In addition, an early adaptive immune response may be required to promote more effective infection control. Indeed, distinct cellular and humoral responses are generated in mild versus severe cases of COVID-19, and it has been reported that specific cellular responses can be detected earlier in non-severe COVID-19 (Zhang et al., 2020). Second, the possible lack of efficacy may be related to plasma administration late in the course of the disease, in which an irregular immune response predominates and is independent of the blockade of viral cell entry achieved by immunoglobulins. Previous randomized trials of convalescent plasma for COVID-19 included patients who had a longer time gap between symptom onset and transfusion as well as more severe disease at enrollment ( $\mathrm{Li}$ et al., 2020)

The results of the systematic study and meta-analysis are presented in the form of forest plots and funnel plots. The forest plot shows an overview of the information from each of the studies examined in the metaanalysis and estimates the overall results (Murti, 2018). Forest plots show visually the magnitude of variation (heterogeneity) between study results. A funnel plot is a diagram in a meta-analysis used to show possible publication bias. The funnel plot shows the relationship between the magnitude of the study effect and the sample size of the effect size of the various studies studied 
which can be measured in different ways (Murti, 2018).

The forest plot results from the Randomized Controlled Study design research article showed that convalescent plasma therapy reduced the risk of death in COVID19 patients and was statistically significant $(\mathrm{RR}=0.77 ; 95 \% \mathrm{CI}=0.64$ to $0.93 ; \mathrm{p}=$ o.008). The heterogeneity of the research data shows $\mathrm{I}^{2}=3 \%$ so that the estimation is carried out using a fixed effect model approach.

This is in line with the results of a study conducted by Salazar et al, (2021) in Texas which stated that convalescent plasma transfusions in COVID-19 patients were performed immediately after hospitalization with high titer RBD IgG anti-spike protein present in convalescent plasma significantly reduce deaths.

In the study of Rasheed et al., (2020) also stated that convalescent plasma therapy is an effective therapy if a donor with high titer SARS-Cov2 antibodies is selected and if the recipient is in the early stages of critical illness, not more than three days in the RCU. Plasma from donors with high titers of SARS-CoV-2 IgG and donors with positive SRAS-CoV-2 IgM showed better therapeutic outcomes than other donors.

\section{AUTHOR CONTRIBUTION}

Fathiyyatu Assa'diy Firda is the lead researcher who chooses topics, searches for and collects research data. CSP Wekadigunawan and Bhisma Murti played a role in analyzing data and reviewing research documents.

\section{CONFLICT OF INTEREST}

There is no conflict of interest in this study.

\section{FUNDING AND SPONSORSHIP}

This study is self-funded.

\section{ACKNOWLEDGMENT}

We are very grateful to the provider databases, PubMed, Science Direct and Google scholar.

\section{REFERENCES}

Abraham J (2019). Passive antibody therapy in COVID-19. Nature Reviews Immunology. 5(3): 4-6. DOI:10.1038/s41577-020-0365-7.

Agarwal A, Mukherjee A, Kumar G, Chatterjee P, Bhatnagar T, Malhotra P (2020). Convalescent plasma in the management of moderate covid-19 in adults in India: open label phase II multicentre randomised controlled trial. BMJ. 371(3939):1-10. DOI:10.1136/BMJ.M3939.

AlQahtani M, Abdulrahman A, Almadani A, Alali SY, Al Zamrooni AM, Hejab AH, Conroy RM et al. (2021). Randomized controlled trial of convalescent plasma therapy against standard therapy in patients with severe COVID-19 disease. Scientific Reports, 11(1): 1-17. DOI:10.1038/s41598-021-89444-5.

Balcells ME, Rojas L, Le Corre N, MartínezValdebenito C, Ceballos ME, Ferrés M, Chang $M$ et al (2021). Early versus deferred anti-SARS-CoV-2 convalescent plasma in patients admitted for COVID-19: A randomized phase II clinical trial. PLoS Medicine, 18(3): 1-18. DOI:10.1371/JOURNAL.PMED.10034 15.

Choi JY (2020). Convalescent plasma therapy for coronavirus disease 2019. In Infection and Chemotherapy. 52(3): 307-316. DOI:10.3947/ic.2020.52.3.307.

Gharbharan A, Jordans CCE, Geurtsvankessel C, Hollander JG Den, Karim F, Mollema FPN et al. (2020). Convalescent Plasma for COVID-19 . A randomized clinical trial. MedRxiv. 14(3):1- 
Firda et al./ Covid-19 Patient Mortality with Convalescent Plasma Therapy

16. DOI:10.1101/2020.07.01.20139857.

Joyner MJ, Carter RE, Senefeld JW, Klassen SA, Mills JR, Johnson PW, Theel ES et al. (2021). Convalescent plasma antibody levels and the risk of death from Covid-19. New England J Med. 384 (11): 1015-1027. DOI:10.1056/NEJMOA2031893.

Li Y, Xia L (2020). Coronavirus Disease 2019 (COVID-19): Role of Chest CT in Diagnosis and Management. American Journal of Roentgenology, 214(32): 1280-1286. DOI:10.2214/AJR.20.22954.

Li ZW, Hu Y, Tong X, Zheng (2020). Effect of Convalescent Plasma Therapy on Time to Clinical Improvement in Patients With Severe and Lifethreatening COVID-19: A Randomized Clinical Trial. JAMA. 324(5): 460470.DOI:10.1001/JAMA.2020.10044

Libster R, Pérez Marc G, Wappner D, Coviello S, Bianchi A, Braem V, Esteban I, et al. (2021). Early High-Titer Plasma Therapy to Prevent Severe Covid-19 in Older Adults. New Eng J Med. 384(7): 610-618. DOI:10.1056/nejmoa2033700.

Mikolajewicz N, Komarova SV (2019). Metaanalytic methodology for basic research: A practical guide. Frontiers in Physiology. 10(5). DOI:10.3389/fphys.2019.00203

Murti B (2018). Prinsip dan Metode Riset Epidemiologi (Epidemiological Research Principles and Methods) (5th ed.). Program Studi Ilmu Kesehatan Masyarakat, Program Pascasarjana, Universitas Sebelas Maret.
O’Donnell MR, Grinsztejn B, Cummings MJ, Justman JE, Lamb MR, Eckhardt CM, Philip NM et al. (2021). A randomized double-blind controlled trial of convalescent plasma in adults with severe COVID-19. Journal of Clinical Investigation. 131(13): 1-9. DOI:10.1172/jci150646.

Rasheed AM, Fatak DF, Hashim HA, Maulood MF, Kabah KK, Almusawi YA, Abdulamir AS (2020). The therapeutic potential of convalescent plasma therapy on treating critically-ill covid19 patients residing in respiratory care units in hospitals in baghdad, Iraq. Infezioni in Medicina, 28(3): 357-366. DOI:10.1101/2020.06.24.20121905.

Salazar E, Christensen PA, Graviss EA, Nguyen DT, Castillo B, Chen J, Lopez $\mathrm{B}$ et al. (2020). Treatment of Coronavirus Disease 2019 Patients with Convalescent Plasma Reveals a Signal of Significantly Decreased Mortality. Am J Pathology. 190(11): 2290-2303. DOI:10.1016/J.AJPATH.2020.08.001

Salazar M, González S, Regairaz L, Ferrando N, González MV, Ramos C, Muñoz MP, et al. (2021). Risk factors for COVID19 mortality: The effect of convalescent plasma administration. PLoS ONE, 16(4): 1-10. DOI:10.1371/journal.pone.0250386.

Simonovich VA, Burgos Pratx LD, Scibona P, Beruto MV, Vallone MG, Vázquez C, Savoy N, et al. (2021). A Randomized Trial of Convalescent Plasma in Covid19 Severe Pneumonia. New England Journal of Medicine, 384(7): 619-629. DOI:10.1056/nejmoa2031304. 